\title{
Land Cover Change in the Boston Mountains, 1973-2000
}

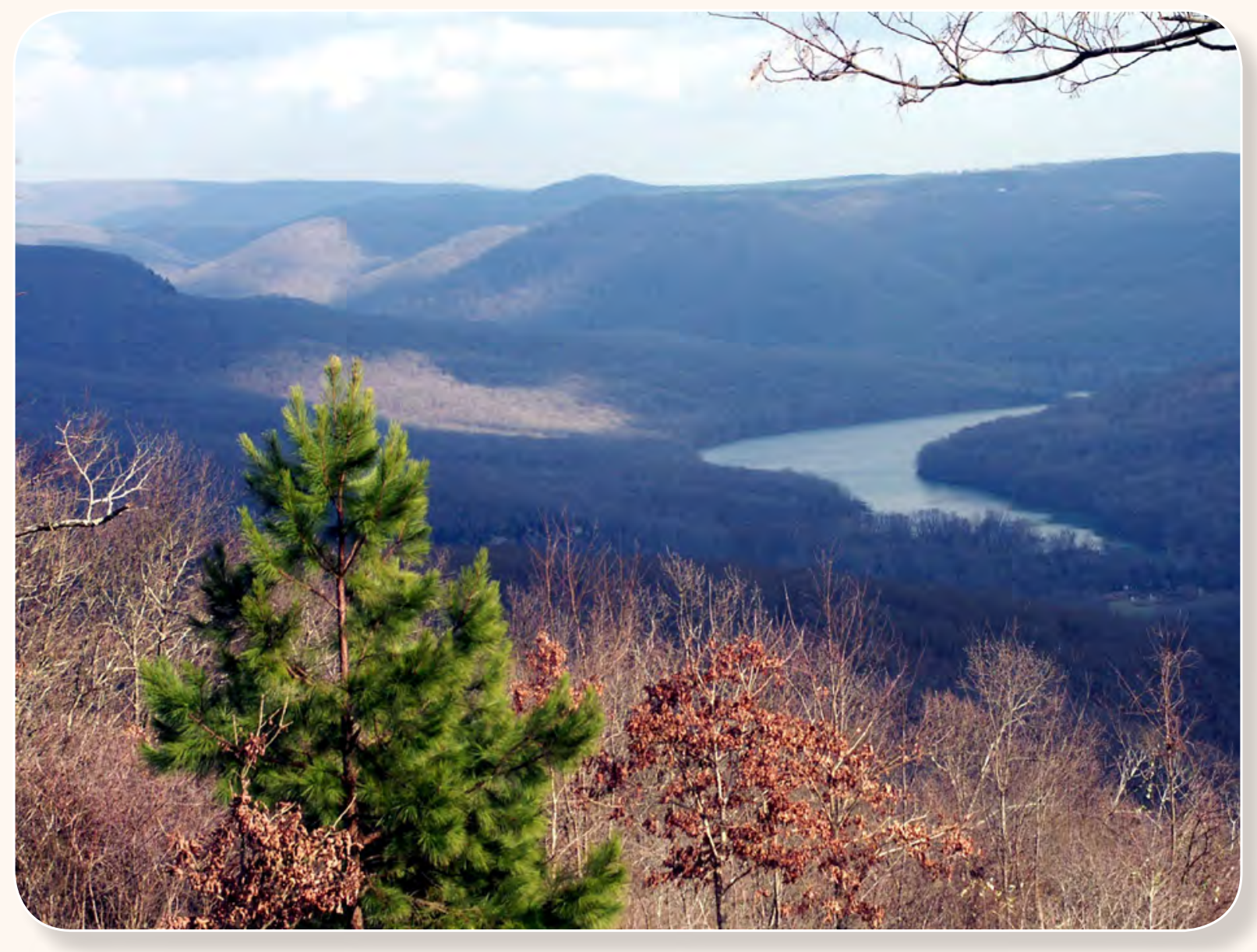

Open-File Report 2009-1281

U.S. Department of the Interior

U.S. Geological Survey 
Cover photograph: Vista view of the Boston Mountains (Thomas R. Loveland, U.S. Geological Survey, 2005) 


\section{Land Cover Change in the Boston Mountains, 1973-2000}

By Krista A. Karstensen

Open-File Report 2009-1281

U.S. Department of the Interior

U.S. Geological Survey 


\section{U.S. Department of the Interior \\ KEN SALAZAR, Secretary \\ U.S. Geological Survey \\ Marcia K. McNutt, Director}

U.S. Geological Survey, Reston, Virginia: 2009

For more information on the USGS—-the Federal source for science about the Earth, its natural and living resources,
natural hazards, and the environment, visit http://www.usgs.gov or call 1-888-ASK-USGS
For an overview of USGS information products, including maps, imagery, and publications,
visit http://www.usgS.gov/pubprod
To order this and other USGS information products, visit http://store.usgs.gov

Any use of trade, product, or firm names is for descriptive purposes only and does not imply endorsement by the U.S. Government.

Although this report is in the public domain, permission must be secured from the individual copyright owners to reproduce any copyrighted materials contained within this report.

Suggested citation:

Karstensen, K.A., 2009, Land-Cover Change in the Boston Mountains, 1973-2000: U.S. Geological Survey Open-File Report 2009-1281, 10 p. 


\section{Contents}

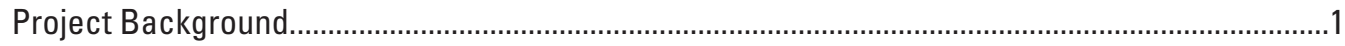

Ecoregion Description.............................................................................................................

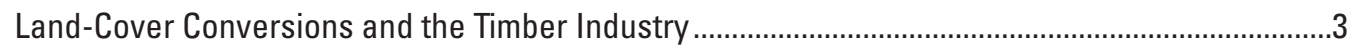

A Historical Perspective of Timber Resources in the Boston Mountains..................................3

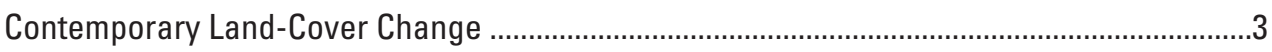

The effect of land-use practices on land-cover change ………………..................................

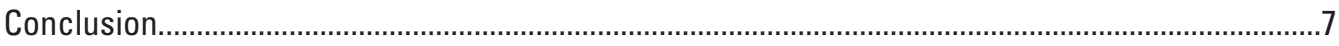

References Cited

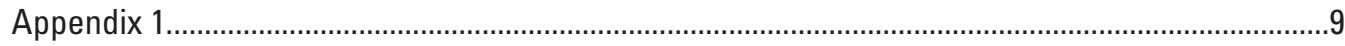

\section{Figures}

1-2. Maps showing:

1. The Boston Mountains and surrounding ecoregions...............................................

2. The 32 randomly selected sample blocks in the Boston Mountains ecoregion and the Ozark National Forest ..........................................................................................

3-4. Photographs showing:

3. Clear-cutting of forest in block 92, Adair County, Oklahoma.....................................

4. Forest thinning in block 76, Newton County, Arkansas ............................................6

\section{Tables}

1. Percentage of the Boston Mountains that experienced spatial change and associated error

2. Percent change in the Boston Mountains computed for each of the four time periods and the associated error at an 85-percent confidence level

3. Estimated area for each land-cover class in the Boston Mountains between 1973 and 2000

4. Leading land-cover conversions in the Boston Mountains during each of the four time periods and overall. 


\section{Conversion Factors}

\begin{tabular}{lcl}
\hline \multicolumn{1}{c}{ Multiply } & By & To obtain \\
\hline centimeter $(\mathrm{cm})$ & Length & \\
kilometer $(\mathrm{km})$ & 0.3937 & inch (in) \\
& 0.6214 & mile (mi) \\
\hline square kilometer $\left(\mathrm{km}^{2}\right)$ & Area & acre \\
square kilometer $\left(\mathrm{km}^{2}\right)$ & 247.1 & square mile $\left(\mathrm{mi}^{2}\right)$ \\
\hline Horizontal coordinate information is referenced to the North American Datum of 1983 \\
(NAD 83).
\end{tabular}




\title{
Land Cover Change in the Boston Mountains, 1973-2000
}

\author{
By Krista A. Karstensen
}

\section{Project Background}

The U.S. Geological Survey (USGS) Land Cover Trends project is focused on understanding the rates, trends, causes, and consequences of contemporary U.S. land-cover change. The objectives of the study are to: (1) to develop a comprehensive methodology for using sampling and change analysis techniques and Landsat Multispectral Scanner (MSS), Thematic Mapper (TM), and Enhanced Thematic Mapper Plus $(\mathrm{ETM}+)$ data to measure regional land-cover change across the United States; (2) to characterize the types, rates, and temporal variability of change for a 30-year period; (3) to document regional driving forces and consequences of change; and (4) to prepare a national synthesis of land-cover change (Loveland and others, 1999).

The 1999 Environmental Protection Agency (EPA) Level III ecoregions derived from Omernik (1987) provide the geographic framework for the geospatial data collected between 1973 and 2000. The 27-year study period was divided into five temporal periods: 1973-1980, 1980-1986, 1986-1992, 1992-2000, and 1973-2000, and the data are evaluated using a modified Anderson Land Use Land Cover Classification System (Anderson and others, 1976) for image interpretation.

The rates of land-cover change are estimated using a stratified, random sampling of 10-kilometer $(\mathrm{km})$ by $10-\mathrm{km}$ blocks allocated within each ecoregion. For each sample block, satellite images are used to interpret land-cover change for the five time periods previously mentioned. Additionally, historic aerial photographs from similar time frames and other ancillary data, such as census statistics and published literature, are used. The sample block data are then incorporated into statistical analyses to generate an overall change matrix for the ecoregion.

Field data of the sample blocks include direct measurements of land cover, particularly ground-survey data collected for training and validation of image classifications (Loveland and others, 2002). The field experience allows for additional observations of the character and condition of the landscape, assistance in sample block interpretation, ground truthing of Landsat imagery, and determination of the driving forces of change identified in an ecoregion.

\section{Ecoregion Description}

The Boston Mountains ecoregion encompasses approximately 112,059 square kilometers $\left(\mathrm{km}^{2}\right)$ of rugged, mountainous terrain across northwest Arkansas and northeast Oklahoma (fig.1). In Arkansas, the principle streams and rivers include Mulberry, and Big Piney Creeks that drain the ecoregion to the south; the Buffalo and Little Red Rivers that drain the ecoregion to the east; and the White and Kings Rivers that drain the ecoregion to the north. In Oklahoma, the most important hydrologic features are Tenkiller Ferry Lake and a small reach of the Arkansas River. Overall, the population density in this ecoregion is low.

The mountains in this ecoregion are remnants of an old, deeply dissected plateau characterized by gently sloping to rolling broad uplands with steep side slopes or vertical escarpments and long, narrow valleys (U.S. Department of Agriculture Natural Resources Conservation Service, 2009). The most recent uplift of the Ozarks, including the Boston Mountains, occurred about 300 million years ago, and the mountains have been weathering and eroding since that time (Guccione, 2008). Elevations range from about 61 meters $(\mathrm{m})$ on valley floors to about $853 \mathrm{~m}$ on the broad mountaintops (Woods and others, 2004b). Elevations in the northern portion of the ecoregion are typically higher. The local relief in this ecoregion ranges from $46 \mathrm{~m}$ to $274 \mathrm{~m}$ (Woods and others, 2004) and is part of the highland areas that has the greatest relief of any formation between the Appalachian Mountains and the Rocky Mountains (Guccione, 2008).

The ecoregion is generally underlain by gently folded sandstone, shale, cherty dolomite and limestone. The soils on the uplands are primarily Ultisols and have low natural fertility and low base saturation (U.S. Department of Agriculture Natural Resources Conservation Service, 1999; Woods and others, 2004a). The soils on the terraces and floodplains that frequently receive new deposits of alluvium are primarily Entisols, which have a high mineral content (U.S. Department of Agriculture Natural Resources Conservation Service, 1999; Woods and others, 2004).

The climate is generally humid, with mean annual precipitation of approximately 127 centimeters $(\mathrm{cm})$, which is generally greater in the north (Woods and others, 2004). Maximum precipitation is in spring and in fall, and the minimum is in midsummer. In the summer months, small streams 

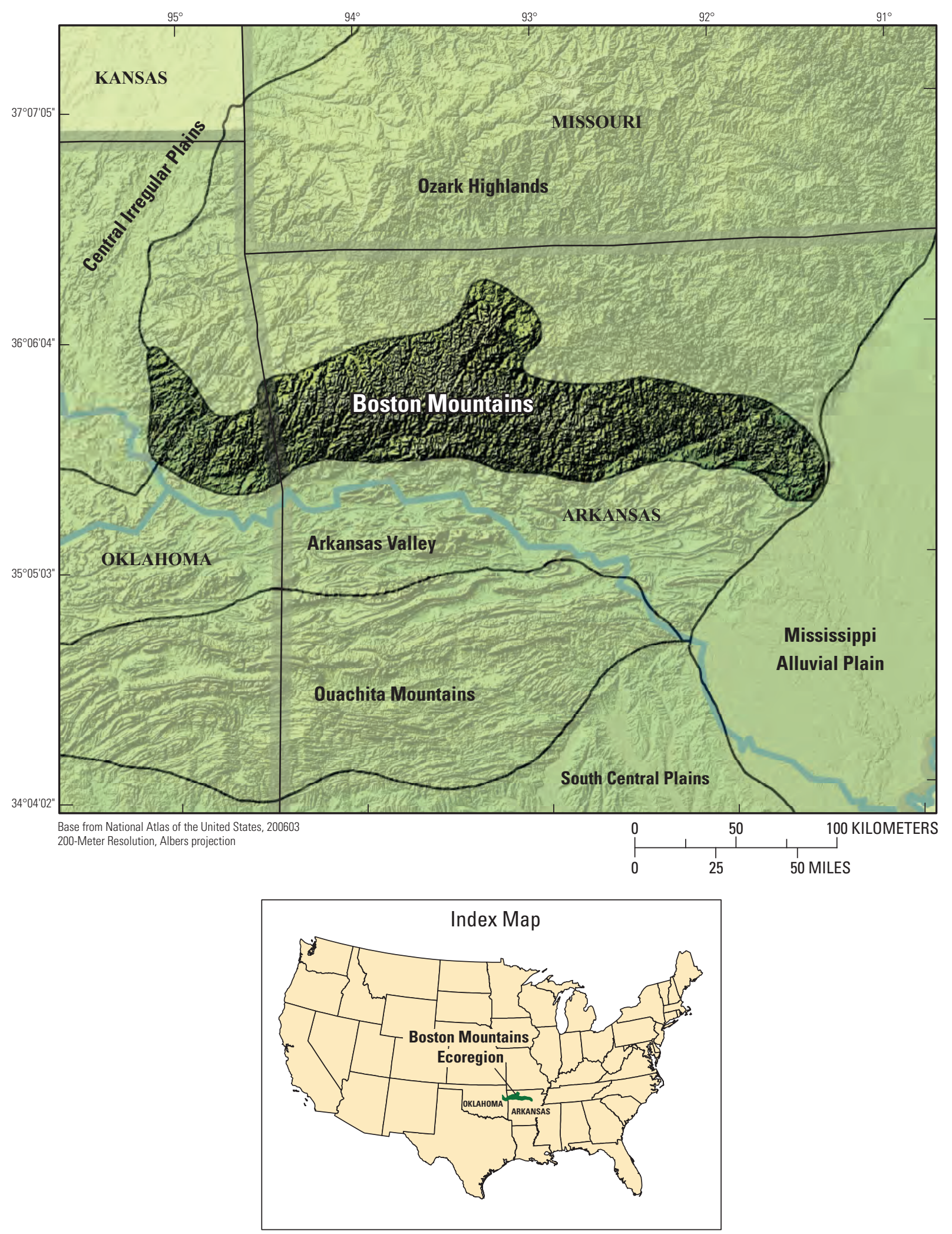

Figure 1. The Boston Mountains and surrounding ecoregions. 
commonly have little or no flow. The ecoregion may be associated with the carbonate-rock aquifers of the Ozark Plateaus aquifer system (Reilly, 2008). Nutrient concentrations generated by agricultural areas present unique concerns to the health of freshwater ecosystems but generally, the water quality in the ecoregion is exceptional (Woods and others, 2004b). While the primary agricultural production activity is raising livestock, historic data indicate that the median total phosphorus concentration in the ecoregion, ranked from highest to lowest, come from wastewater-treatment plants upstream, forested areas, and then a forested and agricultural land mix (Petersen and others, 1998).

Natural vegetation in the ecoregion is comprised mostly of oak-hickory forests, which is the foundation of the timber industry that is critical to the socioeconomic footprint of the ecoregion. Species within hardwood forests on upland areas can include northern red oak, blackjack oak, post oak, black hickory, sugar maple, white oak, chinquapin oak, mockernut hickory, birch, and cottonwood (U.S. Department of Agriculture Farm Service Agency, 2006; Woods and others, 2004b). Southern red oak, sweet gum, willows, and American sycamore are common species found on the narrow floodplains and low terraces (Woods and others, 2004b). Softwood species in the ecoregion include loblolly and shortleaf pines.

Land-use in the ecoregion is principally associated with the foresty and timber industry. And while the generally infertile soils of the ecoregion preclude widespread agricultural land-use in the ecoregion, the areas of low relief are used primarily for pastureland, hayland, and livestock farming. Most of the agricultural land in this ecoregion is associated with the production of poultry and cattle (Petersen and others, 1998). In this study, conversions from the mechanically disturbed class to agriculture are associated with the clearing of forested land to create or expand pastureland.

In addition to forestry and agriculture, the Buffalo River National Park and portions of the Ozark National Forest help promote the recreational use of the ecoregions' streams, lakes, rivers, and forests.

\section{Land-Cover Conversions and the Timber Industry}

\section{A Historical Perspective of Timber Resource in the Boston Mountains}

Between 1958 and 1968, forest area in Arkansas declined by one-eighth (Van Sickle, 1970). Statewide, the most common conversion forest land was to make land available for more than 2 million acres of cropland and pasture (Van Sickle, 1970). While the majority of this change occurred in the neighboring Mississippi Alluvial Plain ecoregion, similar landcover changes were seen in the Boston Mountains. Over the study period, conversions to agriculture from forest were most prevalent in the 1973 to 1980 time period.

In the decade before 1973, softwood volume increased at a much higher rate than that of hardwoods for both growing stock and sawtimber in the Boston Mountains (Van Sickle, 1970). In 1968, most of the forests in the ecoregion were in stands of seedlings and saplings (Van Sickle, 1970). The gross annual growth for most forests in the region of the Boston Mountains was approximately 40 percent of the estimated potential (Van Sickle, 1970). Even though the overall productivity was low, the mountain slopes and benches had good hardwood growing potential (Van Sickle, 1970). Socioeconomically, the poorly developed markets in the region made improvement cuts, cuts made to improve the form or quality of the remaining stand, unprofitable. In 1970 long-range forestry programs could be undertaken in conjunction with efforts to develop recreational opportunities to supplement economic productivity (Van Sickle, 1970).

One of the programs that may have affected the ecoregion is the Forest Incentive Program (FIP). The FIP was originally authorized in 1978 to share up to 65 percent of the costs of tree planting, timber stand improvements, and related practices on non-industrial private forest lands (U.S. Department of Agriculture Natural Resource Conservation Service, 2009). The FIP was intended to assure the Nation's ability to meet demands for timber products and putting more forest under quality management. The program was available in designated counties based on a U.S. Department of Agriculture Forest Service survey of total eligible private timber acreage that was potentially suitable for production of timber products (U.S. Department of Agriculture Natural Resource Conservation Service, 2009). The FIP, if not the benchmark for shaping the land-cover change in the Boston Mountains, may have helped implement tree growth and management on private lands in the later part of the study period. For example, from 1978 to 2007, Arkansas accomplished the following FIP practices: 1) planting 264,882 acres of trees; 2) 113,049 acres of forest stand improvement; 3) 607 acres of site preparation for natural regeneration (David Mason, U.S. Department of Agriculture, written commun., 2009).

\section{Contemporary Land-Cover Change}

The overall spatial change from 1973 to 2000 for the Boston Mountains ecoregion was 5.5 percent $(+/-0.9$ percent) (table 1). A calculated 2.7 percent ( $+/-0.6$ percent) of the ecoregion changed from one land cover to another once during the study period whereas 2.3 percent $(+/-0.4$ percent) changed twice (table 1 ). The amount of change varied only slightly from 1973 to 2000, with the total change (percent of the ecoregion) ranged from a low of 2.0 to 2.7 percent (table 2). The average annual rate of change was highest between 1980 and 1986 at 0.4 percent per year (table 2). Overall, the calculated change was highest in the latter half of the study 
Table 1. Percentage of the Boston Mountains that experienced spatial change and associated error.

$[+/-$, plus or minus; $\%$, percent $]$

\begin{tabular}{ccccccc}
\hline $\begin{array}{c}\text { Number of } \\
\text { changes }\end{array}$ & $\begin{array}{c}\text { Percent } \\
\text { of ecore- } \\
\text { gion }\end{array}$ & $\begin{array}{c}\text { Margin } \\
\text { of error } \\
(+/-\%)\end{array}$ & $\begin{array}{c}\text { Lower } \\
\text { bound } \\
(\%)\end{array}$ & $\begin{array}{c}\text { Upper } \\
\text { bound } \\
(\%)\end{array}$ & $\begin{array}{c}\text { Standard } \\
\text { error } \\
(\%)\end{array}$ & $\begin{array}{c}\text { Relative } \\
\text { error } \\
(\%)\end{array}$ \\
\hline 1 & 2.7 & 0.6 & 2.2 & 3.3 & 0.4 & 14.1 \\
2 & 2.3 & .4 & 1.9 & 2.6 & .2 & 10.5 \\
3 & .5 & .1 & .4 & .6 & .1 & 17.4 \\
4 & 0 & 0 & 0 & 0 & 0 & 43.9 \\
$\begin{array}{c}\text { Overall spatial } \\
\text { change }\end{array}$ & 5.5 & .9 & 4.7 & 6.4 & .6 & 10.4 \\
\hline
\end{tabular}

Table 2. Percent change in the Boston Mountains computed for each of the four time periods and associated error at an 85-percent confidence level.

[+/-, plus or minus; $\%$, percent $]$

\begin{tabular}{cccccccc}
\hline Period & $\begin{array}{c}\text { Total change } \\
\text { (\% of ecore- } \\
\text { gion) }\end{array}$ & $\begin{array}{c}\text { Margin } \\
\text { of error } \\
(+/-\%)\end{array}$ & $\begin{array}{c}\text { Lower } \\
\text { bound } \\
(\%)\end{array}$ & $\begin{array}{c}\text { Upper } \\
\text { bound } \\
(\%)\end{array}$ & $\begin{array}{c}\text { Standard } \\
\text { error } \\
(\%)\end{array}$ & $\begin{array}{c}\text { Relative } \\
\text { error } \\
(\%)\end{array}$ & $\begin{array}{c}\text { Average } \\
\text { rate } \\
\text { (\% per year) }\end{array}$ \\
\hline $1973-1980$ & 2.0 & 0.5 & 1.5 & 2.5 & 0.3 & 17.1 & 0.3 \\
$1980-1986$ & 2.1 & .3 & 1.8 & 2.5 & .2 & 10.1 & .4 \\
$1986-1992$ & 2.0 & .3 & 1.7 & 2.4 & .2 & 10.3 & .3 \\
$1992-2000$ & 2.7 & .5 & 2.2 & 3.1 & .3 & 11.7 & .3 \\
\hline
\end{tabular}

Table 3. Estimated area for each land-cover class in the Boston Mountains between 1973 and 2000.

[+/-, plus or minus; \%, percent $]$

\begin{tabular}{|c|c|c|c|c|c|c|c|c|c|c|c|c|c|c|c|c|c|c|c|c|}
\hline & \multicolumn{2}{|c|}{ Water } & \multicolumn{2}{|c|}{ Developed } & \multicolumn{2}{|c|}{$\begin{array}{c}\text { Mechanically } \\
\text { disturbed }\end{array}$} & \multicolumn{2}{|c|}{ Mining } & \multicolumn{2}{|c|}{ Barren } & \multicolumn{2}{|c|}{ Forest } & \multicolumn{2}{|c|}{$\begin{array}{l}\text { Grassland/ } \\
\text { Shrubland }\end{array}$} & \multicolumn{2}{|c|}{ Agriculture } & \multicolumn{2}{|c|}{$\begin{array}{l}\text { Wet- } \\
\text { lands }\end{array}$} & \multicolumn{2}{|c|}{$\begin{array}{c}\text { Non-mechanical- } \\
\text { ly disturbed }\end{array}$} \\
\hline & $\%$ & $+/-$ & $\%$ & $+/-$ & $\%$ & $+/-$ & $\%$ & $+/-$ & $\%$ & $+/-$ & $\%$ & $+/-$ & $\%$ & $+/-$ & $\%$ & $+/-$ & $\%$ & $+/-$ & $\%$ & $+/-$ \\
\hline 1973 & 1.3 & 0.8 & 0.9 & 0.7 & 0.3 & 0.2 & 0 & 0 & 0 & 0 & 77.5 & 3.5 & 0.7 & 0.4 & 19.3 & 3.3 & 0 & 0 & 0 & 0 \\
\hline 1980 & 1.3 & .8 & .9 & .7 & .9 & .2 & 0 & 0 & 0 & 0 & 77.0 & 3.5 & .6 & .2 & 19.4 & 3.3 & 0 & 0 & 0 & 0 \\
\hline 1986 & 1.2 & .8 & 1.0 & .7 & .6 & .1 & 0 & 0 & 0 & 0 & 77.1 & 3.5 & .6 & .1 & 19.5 & 3.4 & 0 & 0 & 0 & 0 \\
\hline 1992 & 1.3 & .8 & 1.0 & .7 & .8 & .2 & 0 & 0 & 0 & 0 & 76.7 & 3.5 & .5 & .1 & 19.7 & 3.4 & 0 & 0 & 0 & 0 \\
\hline 2000 & 1.3 & .8 & 1.0 & .7 & 1.4 & .4 & 0 & 0 & 0 & 0 & 75.8 & 3.6 & .4 & .1 & 20.0 & 3.4 & 0 & 0 & 0 & 0 \\
\hline $\begin{array}{l}\text { Net } \\
\quad \text { Change }\end{array}$ & .1 & 0 & .2 & .1 & 1.0 & .4 & 0 & 0 & 0 & 0 & -1.7 & .5 & -.3 & .3 & .7 & .2 & 0 & 0 & 0 & 0 \\
\hline $\begin{array}{l}\text { Gross } \\
\text { Change }\end{array}$ & .2 & .1 & .2 & .1 & 3.1 & .6 & 0 & 0 & 0 & 0 & 3.6 & .7 & 1.3 & .4 & 1.2 & .2 & 0 & 0 & 0 & 0 \\
\hline
\end{tabular}

period, whereas the average annual rate of change was higher in the earlier time periods.

The forest and mechanically disturbed classes underwent the most change during the study period (table 3 ). The forest class had a net loss of 1.7 percent $(+/-0.5$ percent) whereas the mechanically disturbed class had a net gain of 1.0 percent (+/- 0.4 percent). Forest loss in the ecoregion can be attributed to the logging practices associated with the mechanically disturbed land-cover class.

\section{The effect of land-use practices on land-cover change}

In a 1999 assessment conducted by the U.S. Department of Agriculture, Forest Service's Southern Research Station, primary wood-using mills were canvassed to document changes in product output and residue use. This assessment complimented the Forest Inventory and Analysis (FIA) periodic inventory of volume and removals from Arkansas' timberland (Bentley and others, 2002). In 1999, the 


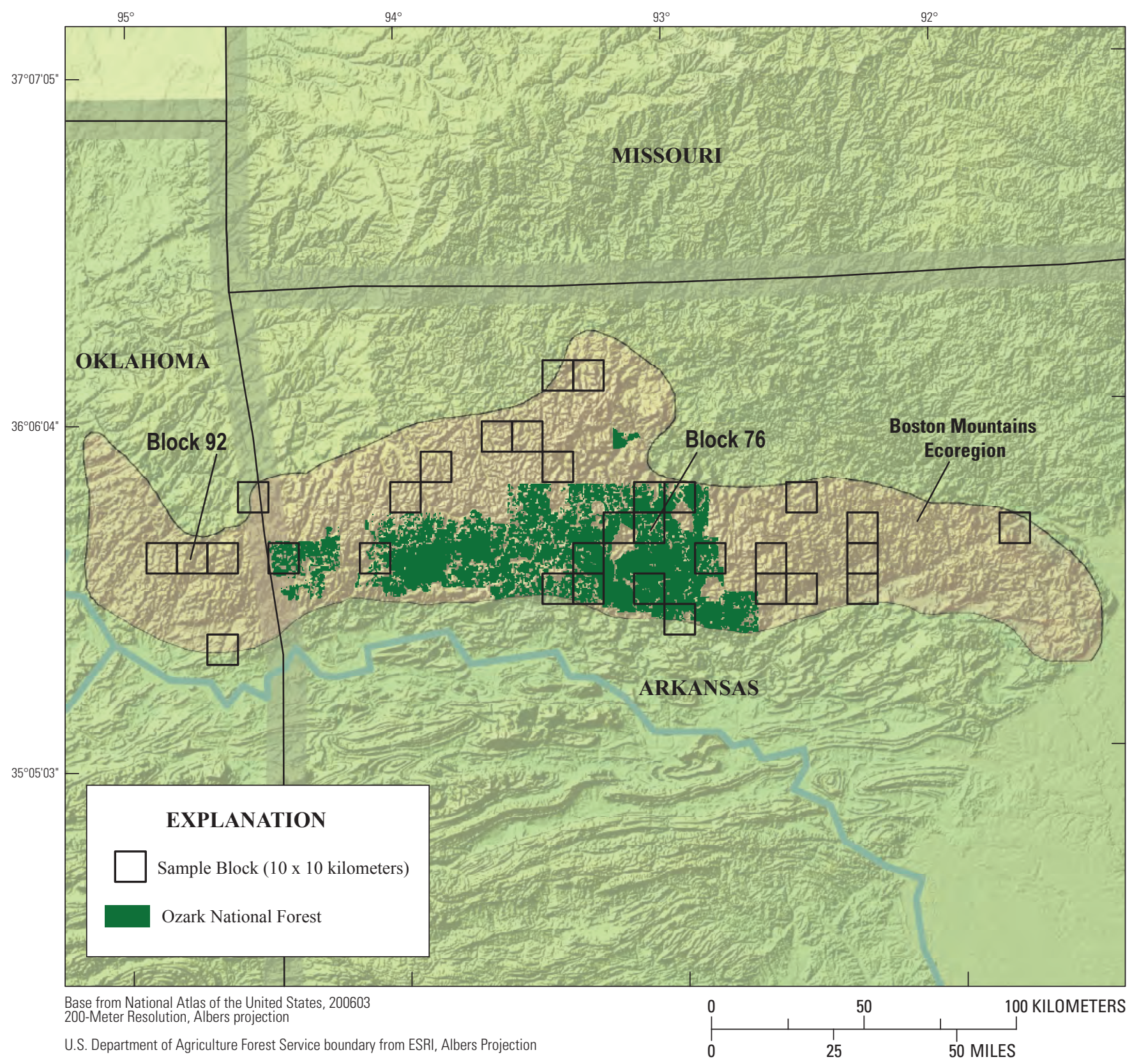

Figure 2. The 32 randomly selected sample blocks are in the Boston Mountains ecoregion and the Ozark National Forest.

roundwood softwood output for all industrial products in the ecoregion ranged from less than 5 cubic feet $\left(\mathrm{ft}^{3}\right)$ produced per acre of census land area in the north and west to 5 to 20 $\left(\mathrm{ft}^{3}\right)$ in the south and east (Bentley and others, 2002). A cubic foot is a unit of volume measure, wood equivalent to a solid cube that measures 12 inches (in) by 12 in by 12 in or 1,728 cubic inches (Albritton, 2001). In the same year, the intensity of roundwood hardwood output for all industrial products in the ecoregion generally was less than that of softwoods, with most of the counties in the ecoregion producing less than five cubic feet per acre ( $\mathrm{ft}^{3}$-acre). Only Independence, Cleburne, and Stone Counties produced 5 to $10 \mathrm{ft}^{3}$-acre (Bentley and others, 2002). When compared to results from 1996, the 1999 data indicated that overall, the ecoregion produced 62 million of roundwood, which was an increase of 13 percent, as compared to a 3 percent increase for softwood (Bentley and others, 2002). Overall, the primary output roundwood product for the ecoregion in 1999 was saw logs (Bentley, 2002).

The land-cover statistics reflect a typical transition of land-cover responses to the land use of the logging and timber industry that play a large role in the ecoregion. Recently, some changes in forest structure have occurred, but overall, forest remained the second leading land cover for all of the time periods. The structure of the forests in the Boston Mountains 


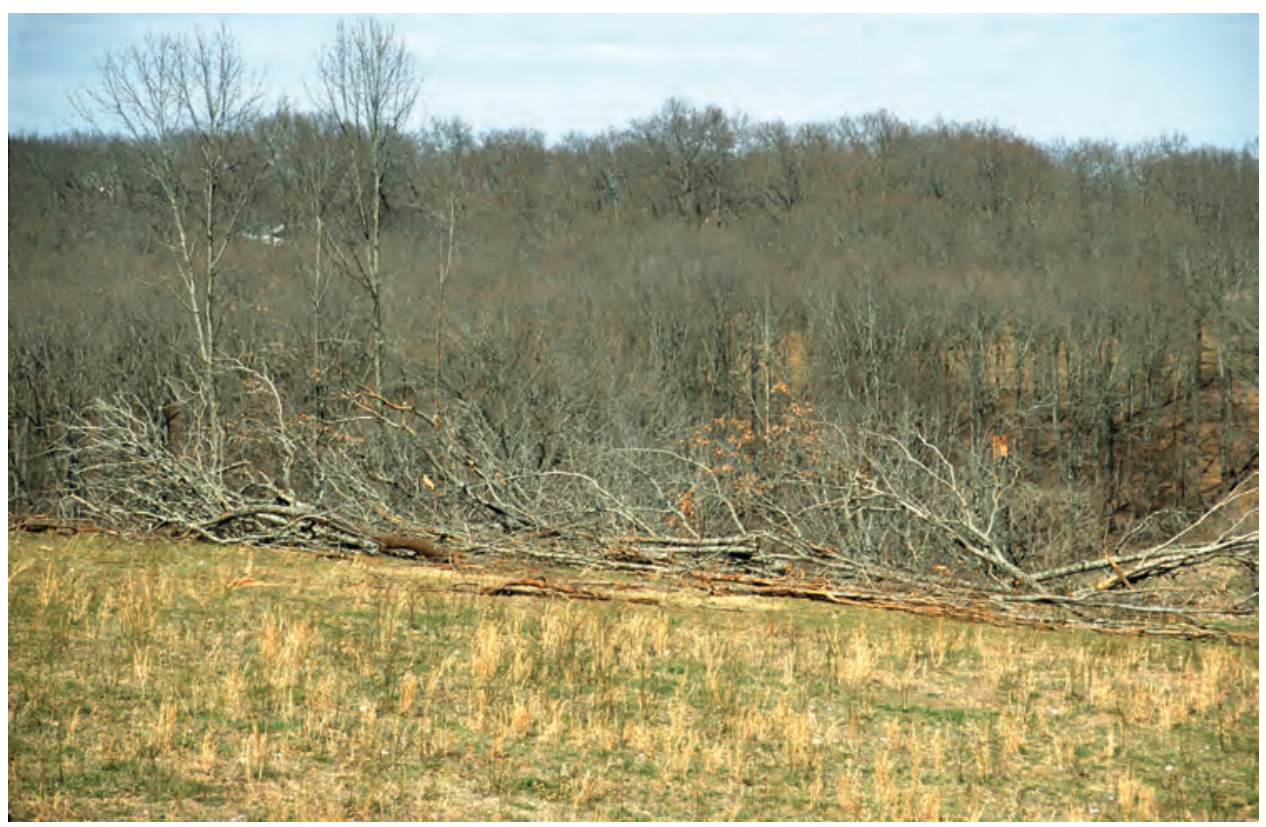

Figure 3. Clear-cutting of forest in block 92, Adair County, Oklahoma (Thomas R. Loveland, U.S. Geological Survey, 2005).

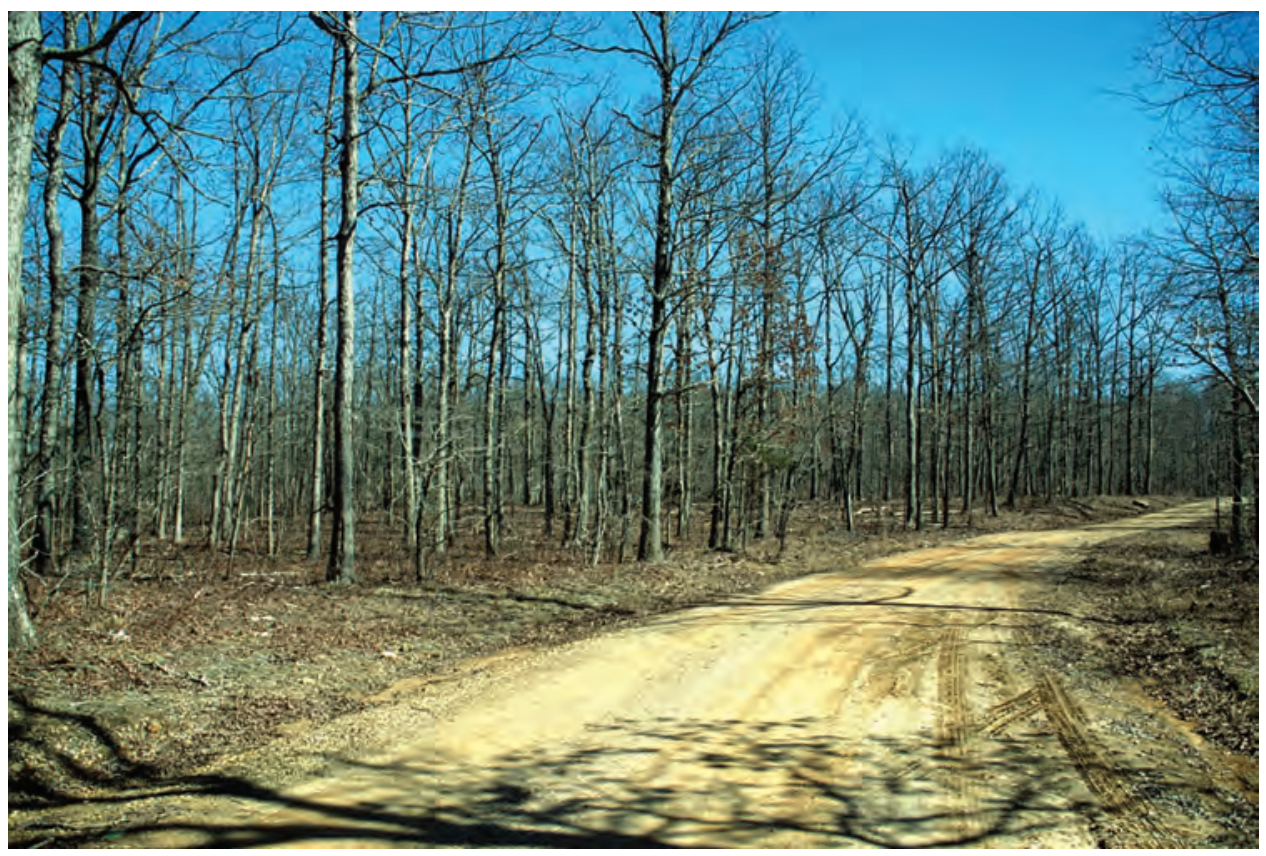

Figure 4. Forest thinning in block 76, Newton County, Arkansas (Thomas R. Loveland, U.S. Geological Survey, 2005).

ecoregion have recently been affected by regional drought (Heitzman and others, 2007) and fire but overall, the structure may be more affected by ownership and management practices.

Timberland in the ecoregion increased between the 1988 FIA and 1995 FIA, and the majority was held in nonindustrial private ownership (Rosson and London, 1997). Moreover, the growth and removal of sawtimber on timberland (board feet per year) on undifferentiated private land was much higher than that on National Forest land, and other Federal and State land (U.S. Department of Agriculture Forest Service, 1995). A board foot is a unit of area for measuring lumber equaling 12 in by 12 in by 1 in (Albritton, 2001). The Ozark National Forest is a large part of the ecoregion (fig. 2). While clear-cut practices may have occurred in blocks on the private lands, such as block 92 (fig.3), thinning practices are used on public lands as seen in block 76 (fig.4) and have a significant effect on the forest ecology. 


\section{Conclusion}

This paper presents some of the influences that the timber industry may have had on shaping the contemporary land-cover changes in the Boston Mountains. The leading land-cover conversion in all the time periods was from forest to mechanically disturbed (table 4). The Boston Mountains ecoregion lost $590 \mathrm{~km}^{2}$ of forest to the mechanically disturbed class between 1973 and 2000. The second leading change was from grassland/shrubland to forest which likely is to be associated with the transition of forest regeneration due to the need for more productive forest land and a decline in cattle volume which allowed grazing land to return to forest stand growth (L. Handley, U.S. Geological Survey, written commun., 2009).

Table 4. Leading land cover conversions in the Boston Mountains during each of four time periods and overall.

$\left[\mathrm{km}^{2}\right.$, square kilometer; $\mathrm{n} / \mathrm{a}$, not applicable]

\begin{tabular}{|c|c|c|c|c|c|c|c|}
\hline Period & From class & To class & $\begin{array}{c}\text { Area } \\
\text { changed } \\
\left(\mathrm{km}^{2}\right)\end{array}$ & $\begin{array}{c}\text { Margin of } \\
\text { error } \\
\left(+/-\mathrm{km}^{2}\right)\end{array}$ & $\begin{array}{c}\text { Standard } \\
\text { error } \\
\left(\mathbf{k m}^{2}\right)\end{array}$ & $\begin{array}{c}\text { Percent } \\
\text { of ecore- } \\
\text { gion }\end{array}$ & $\begin{array}{c}\text { Percent } \\
\text { of all } \\
\text { changes }\end{array}$ \\
\hline \multirow[t]{7}{*}{$1973-1980$} & Forest & Mechanically disturbed & 145 & 30 & 20 & 0.9 & 41.9 \\
\hline & Grassland/Shrubland & Forest & 80 & 58 & 40 & .5 & 23.0 \\
\hline & Mechanically disturbed & Grassland/Shrubland & 33 & 19 & 13 & .2 & 9.4 \\
\hline & Forest & Agriculture & 29 & 18 & 12 & .2 & 8.4 \\
\hline & Agriculture & Grassland/Shrubland & 24 & 12 & 8 & .1 & 6.9 \\
\hline & Other & Other & 36 & $\mathrm{n} / \mathrm{a}$ & $\mathrm{n} / \mathrm{a}$ & .2 & 10.4 \\
\hline & & & 347 & & & 2 & 100 \\
\hline \multirow[t]{7}{*}{ 1980-1986 } & Forest & Mechanically disturbed & 84 & 20 & 14 & 0.5 & 23.0 \\
\hline & Grassland/Shrubland & Forest & 68 & 23 & 15 & .4 & 18.6 \\
\hline & Mechanically disturbed & Agriculture & 52 & 18 & 12 & .3 & 14.3 \\
\hline & Mechanically disturbed & Grassland/Shrubland & 49 & 13 & 9 & .3 & 13.4 \\
\hline & Mechanically disturbed & Forest & 45 & 26 & 17 & .3 & 12.4 \\
\hline & Other & Other & 67 & $\mathrm{n} / \mathrm{a}$ & $\mathrm{n} / \mathrm{a}$ & .4 & 18.4 \\
\hline & & & 364 & & & 2.1 & 100 \\
\hline \multirow[t]{7}{*}{ 1986-1992 } & Forest & Mechanically disturbed & 130 & 27 & 18 & 0.8 & 37.3 \\
\hline & Grassland/Shrubland & Forest & 69 & 16 & 11 & .4 & 19.7 \\
\hline & Mechanically disturbed & Agriculture & 38 & 13 & 9 & .2 & 10.8 \\
\hline & Mechanically disturbed & Grassland/Shrubland & 31 & 14 & 10 & .2 & 8.8 \\
\hline & Agriculture & Grassland/Shrubland & 22 & 9 & 6 & .1 & 6.4 \\
\hline & Other & Other & 59 & $\mathrm{n} / \mathrm{a}$ & $\mathrm{n} / \mathrm{a}$ & .3 & 17.0 \\
\hline & & & 349 & & & 2 & 100 \\
\hline \multirow[t]{7}{*}{$1992-2000$} & Forest & Mechanically disturbed & 231 & 73 & 49 & 1.4 & 50.6 \\
\hline & Grassland/Shrubland & Forest & 52 & 16 & 11 & .3 & 11.5 \\
\hline & Mechanically disturbed & Agriculture & 51 & 16 & 11 & .3 & 11.2 \\
\hline & Mechanically disturbed & Forest & 41 & 18 & 12 & .2 & 9.1 \\
\hline & Mechanically disturbed & Grassland/Shrubland & 38 & 13 & 9 & .2 & 8.3 \\
\hline & Other & Other & 43 & $\mathrm{n} / \mathrm{a}$ & $\mathrm{n} / \mathrm{a}$ & .3 & 9.4 \\
\hline & & & 457 & & & 2.7 & 100 \\
\hline Overall & Forest & Mechanically disturbed & 590 & 102 & 69 & 3.5 & 30.0 \\
\hline \multirow[t]{6}{*}{$1973-2000$} & Grassland/Shrubland & Forest & 269 & 88 & 59 & 1.6 & 13.7 \\
\hline & Mechanically disturbed & Grassland/Shrubland & 150 & 44 & 30 & .9 & 7.6 \\
\hline & Mechanically disturbed & Agriculture & 147 & 35 & 24 & .9 & 7.5 \\
\hline & Mechanically disturbed & Forest & 115 & 53 & 36 & .7 & 5.8 \\
\hline & Other & Other & 694 & $\mathrm{n} / \mathrm{a}$ & $\mathrm{n} / \mathrm{a}$ & 4 & 35.3 \\
\hline & & & 1965 & & & 11.5 & 100 \\
\hline
\end{tabular}


Similarly, the third leading land conversion of mechanically disturbed to grassland/shrubland is likely a reflection of new tree growth following the cutting of stands for timber. While land-cover changes in the ecoregion are largely associated with forestry practices and the timber industry, it is important to note that forest land was also cleared for agricultural land-use.

\section{References Cited}

Albritton, T., 2001, Basic forest measurements, Alabama Forestry Commission, accessed October 29, 2009, at URL http://www.forestry.state.al.us/TF2001.aspx? $b v=5 \& s=0$

Anderson, J.R., Hardy, E.E., Roach, J.T., and Witmer, R.E., 1976, A land use and land cover classification system for use with remote sensor data, U.S. Geological Survey Professional Paper 964, 41 p.

Bentley, J.W., Johnson, T.G., and Howell, M., 2002, Arkansas' timber industry-an assessment of timber product output and use, 1999: U.S. Department of Agriculture Forest Service Southern Research Station, Resource Bulletin SRS-79, 41 p.

Guccione, M.J., 2008, Boston Mountains, The Encyclopedia of Arkansas history and culture, accessed December 3, 2009, at URL http://www.encyclopediaofarkansas.net/encyclopedia/entry-detail.aspx?entryID $=2389$

Heitzman, E., Grell, A., Spetich, M., and Starkey, D., 2007, Changes in forest structure associated with oak decline in severely impacted areas of northern Arkansas: Southern Journal of Applied Forestry, Society of American Foresters, v. 31, no. 1, p. 17-22.

Loveland, T.R., Sohl, T.L., Sayler, K.L., Gallant, A.L., Dwyer, J., Vogelmann, J., Zylstra, G., Wade, T., Edmonds, C., Chaloud, D., and Jones, B., 1999, Land cover trends: Rates, causes, and consequences of late-twentieth century U.S. land cover change: U.S. Environmental Protection Agency Journal, p. 1-52.

Loveland, T.R., Sohl, T.L., Stehman, S.V., Gallant, A.L., Sayler, K.L., and Napton, D.E., 2002, A strategy for estimating the rates of recent United States land cover changes: Photogrammetric Engineering and Remote Sensing, v. 68, no. 10, p. 1,091-1,099.

Omernik, J.M., 1987, Ecoregions of the conterminous United States: Annals of the Association of American Geographers, v. 77 , no. 1 , p. $118-125$.
Petersen, J.C., Adamski, J.C., Bell, R.W., Davis, J.V., Femmer, S.R., Freiwald, D.A., and Joseph, R.L., 1998, Water quality in the Ozark Plateaus, Arkansas, Kansas, Missouri, and Oklahoma, 1992-95: U.S. Geological Survey Circular 1158, $33 \mathrm{p}$.

Reilly, T.E., Dennehy, K.F., Alley, W.M., and Cunningham, W.L., 2008, Ground-Water Availability in the United States: U.S. Geological Survey Circular 1323, p. 8-9.

Rosson, J.F., Jr., and London, J.D., 1997, Forest statistics for Arkansas' Ozark Counties - 1995: U.S. Department of Agriculture Forest Service Southern Research Station, Resource Bulletin SRS-15, p. 1-4.

U.S. Department of Agriculture Farm Service Agency, 2006, Programmatic environmental assessment for implementation of the Conservation Reserve Enhancement Program Agreement for Oklahoma, accessed July 16, 2009, at URL http://www.fsa.usda.gov/Internet/FSA_File/ok_ final_020408.pdf

U.S. Department of Agriculture Forest Service, 1995, Forest Inventory and Analysis National Program, accessed July 13, 2009, at URL http://www.fia.fs.fed.us/.

U.S. Department of Agriculture Natural Resources Conservation Service, 1999, Soil taxonomy: A basic system of soil classification for making and interpreting soil surveys, accessed July 13, 2009, at URL ftp://ftp-fc.sc.egov.usda.gov/ NSSC/Soil_Taxonomy/tax.pdf

U.S. Department of Agriculture Natural Resources Conservation Service, 2009, Major land resource areas, accessed July 15, 2009, at URL http://www.ar.nrcs.usda.gov/soils/ mo16_mlra.html

Van Sickle, C.C., 1970, Arkansas forest resource patterns: U.S. Department of Agriculture Forest Service Southern Forest Experiment Station, p. 1-34.

Woods, A.J., Foti, T.L., Chapman, S.S., Omernik, J.M., Wise, J.A., Murray, E.O., Prior, W.L., Pagan, J.B., Cornstock, J.A., and Radford, M., 2004a, Ecoregions of Arkansas: Reston, Virginia, United States Geological Survey, accessed July 13, 2009, at URL ftp://ftp.epa.gov/wed/ecoregions/ar/ ar_front.pdf

Woods, A.J., Foti, T.L., Chapman, S.S., Omernik, J.M., Wise, J.A., Murray, E.O., Prior, W.L., Pagan, J.B., Cornstock, J.A., and Radford, M., 2004b, Ecoregions of Arkansas: Reston, Virginia, U.S. Geological Survey, accessed July 13, 2009, at URL ftp://ftp.epa.gov/wed/ecoregions/ar/ar_back. $p d f$ 
Appendix 1 


\section{The following definitions describe each land- cover class:}

Water Areas persistently covered with water, such as streams, canals, lakes, reservoirs, bays, or oceans.

Developed Areas of intensive use with much of the land covered with structures or anthropogenic impervious surfaces (e.g., high-density residential, commercial, industrial, roads, etc.) or less intensive uses where the land cover matrix includes both vegetation and structures (e.g., low-density residential, recreational facilities, cemeteries, parking lots, utility corridors, etc.), including any land functionally related to urban or built-up environments (e.g., parks, golf courses, etc.).

Mechanically disturbed Land in an altered and often unvegetated state that, due to disturbances by mechanical means, is in transition from one cover type to another. Mechanical disturbances include forest clear-cutting, earthmoving, scraping, chaining, reservoir drawdown, and other similar humaninduced changes.

Mining Areas with extractive mining activities that have a significant surface expression. This includes (to the extent that these features can be detected) mining buildings, quarry pits, overburden, leach, evaporative, tailings, or other related components.

Barren Land comprised of soils, sand, or rocks where less than 10 percent of the area is vegetated. Barren lands are usually naturally occurring.
Forest Tree-covered land where the tree cover density is greater than 10 percent. Note that cleared forest land (i.e., clear-cuts) is mapped according to current cover (e.g., mechanically disturbed or grassland/shrubland).

Grassland/Shrubland Land predominately covered with grasses, forbs, or shrubs. The vegetated cover must comprise at least 10 percent of the area.

Agriculture Land in either a vegetated or an unvegetated state used for the production of food and fiber. This includes cultivated and uncultivated croplands, hay lands, pasture, orchards, vineyards, and confined livestock operations. Note that forest plantations are considered forests regardless of the use of the wood products.

Wetland Land where water saturation is the determining factor in soil characteristics, vegetation types, and animal communities. Wetlands usually contain both water and vegetated cover.

Non-mechanically disturbed Land in an altered and often unvegetated state that, due to disturbances by non-mechanical means, is in transition from one cover type to another. Nonmechanical disturbances are caused by fire, wind, floods, animals, and other similar phenomena.

Ice and Snow Land where the accumulation of snow and ice does not completely melt during the summer period (e.g., alpine glaciers and snowfields). 
Publishing support provided by:

Rolla Publishing Service Center

For more information concerning this publication, contact:

Director

U.S. Geological Survey

Mid-Continent Geographic Science Center

1400 Independence Road

Rolla, M0 65401

(573) 308-3550

Or visit the Mid-Continent Geographic Science Center website at: http://mcgsc.usgs.gov/ 


